Journal of Advanced Biomedical and Pharmaceutical Sciences JABPS Journal Homepage: http://jabps.journals.ekb.eg

\title{
Design, Synthesis, Molecular Modeling and Biological Evaluation of Novel 1,5- Diarylpyrazole Carboxamide Derivatives as Antiproliferative Agents
}

Osama M. Soltan ${ }^{1}$, Mai E. Shoman ${ }^{2}$, Salah A. Abdel-Aziz ${ }^{1,3}$, Keita Nagaoka ${ }^{4}$, Atsushi Narumi ${ }^{5}$, Hiroyuki Konno ${ }^{4}$, Mohamed Abdel-Aziz ${ }^{2 * *}$

${ }^{1}$ Department of Pharmaceutical Chemistry, Faculty of Pharmacy, Al-Azhar University, Assiut 71524, Egypt

${ }^{2}$ Department of Medicinal Chemistry, Faculty of Pharmacy, Minia University, 61519 Minia, Egypt

${ }^{3}$ Department of Pharmaceutical Chemistry, Faculty of Pharmacy, Deraya 61111 University, Minia, Egypt

${ }^{4}$ Department of Biological Engineering, Graduate School of Science and Engineering, Yamagata University, Jonan 4-3-16,

Yonezawa 992-8510, Japan

${ }^{5}$ Department of Organic Materials Science, Graduate School of Organic Materials Science, Yamagata University, Jonan 4-3-16,

Yonezawa 992-8510, Japan

\section{Abstract}

A series of novel 1,5-diarylpyrazole carboxamide derivatives was designed and synthesized. All the synthesized compounds were biologically evaluated for their in vitro cytotoxic activities against a panel of five cancer cell lines namely, DLD, Hela, K-562, SUIT and HepG-2. The results revealed that compound $\mathbf{5 c}$ exhibited the most prominent cytotoxic effect against four tested cell lines with growth inhibition percentages ranged from 75.95 to $123 \%$ and $\mathrm{IC}_{50}$ values of 17.20 and $21.20 \mu \mathrm{M}$ comparable to that of daunorubicin as a control drug ( $\mathrm{IC}_{50}$ values of 13.30 and $22 \mu \mathrm{M}$ ) against K-562 and Hep-G2 cell lines, respectively. Molecular docking study suggested the ability of the tested compounds to inhibit EGFR-TK. Data showed that $\mathbf{5 c}$ possess the ability to bind to erlotinib binding site forming a stable complex with energy scores -7.73 compared to -7.63 for erlotinib. It potentially forms three hydrogen bonds with LYS 721 and GLU 638 residues. Data suggests that compound $\mathbf{5 c}$ is a promising lead in the design of further EGFR inhibitors.

Key words

Anticancer; 1,5-diarylpyrazole derivatives; EGFR-TKI; Molecular docking.<smiles>CNC(=O)c1ccc(Oc2ccc(NC(=O)Nc3ccc(Cl)c(C(F)(F)F)c3)cc2)cn1</smiles><smiles>NC(=S)N1N=C(c2ccccc2)CC1c1ccc(F)cc1</smiles>

IV

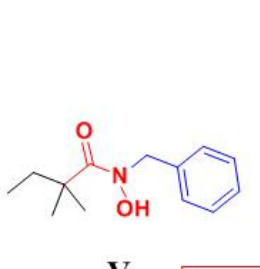

Merging pharmacophores

Anticancer activity

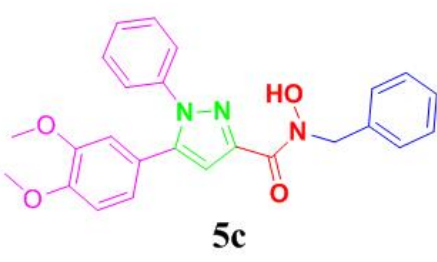

$\mathrm{IC}_{50}=\mathbf{1 7 . 2 0} \mu \mathrm{M}(\mathrm{K}-562)$

$\mathrm{IC}_{50}=21.20 \mu \mathrm{M}($ Hep-G2)

Cytotoxicity $=123 \%($ Hep-G2)

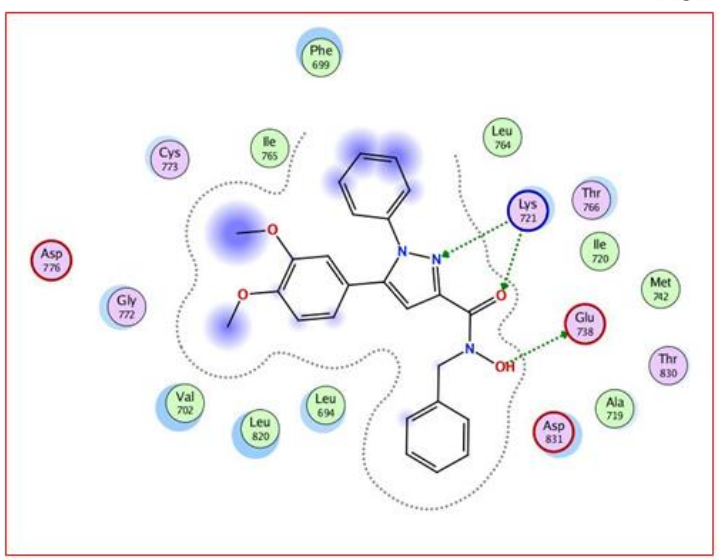




\section{Introduction}

Globally, cancer is the second leading cause of death after cardiovascular diseases $[1,2]$. Moreover, cancer morbidity and mortality are expected to increase for a long time $[3,4]$. In 2018 , 18.1 million new cancer cases with 9.6 million deaths were recorded all over the world [5].

Furthermore, the development of cancer therapy is a pressing issue, chemotherapy remains the cornerstone of cancer elimination, but drug resistance and side effects have already become the major challenges for effective cancer chemotherapy. Therefore, it's urgent to develop novel anticancer agents with prominent in vivo efficacy against drug-resistant with low side effects [6]. One current area of development in cancer therapy is development of tyrosine kinase inhibitors as targeted anticancer therapeutics.

Epidermal growth factor receptor (EGFR), a transmembranebound protein involved in cellular signal transduction processes that has important regulatory functions affecting tumor growth and progression. These include cell proliferation, differentiation, migration, apoptosis, and angiogenesis [7].

EGFR, has been extensively studied and clinically validated as a target for cancer treatment, being over-expressed in a wide number of human tumors and associated with cancer proliferation, angiogenesis, and metastasis [8,9]. EGFR pathway is dysregulated in multiple cancers. For example, it is overexpressed in $\sim 80 \%$ of non-small cell lung cancer (NSCLC) $[10,11]$ and mutated in $20 \%$ of NSCLC [12]. In addition to it is overexpression in breast cancer.[9] FDA approved several drugs targeting EGFR such as sorafenib I [13], sunitinib II [14], erlotinib [15] III (Figure 1), lapatinib [16], gefitinib [17] and osimertinib [18].

Most of these developed drugs usually binds to ATP active site of EGFR-TK. The design of such drugs was introduced based upon the structural analysis of reported examples of tyrosine kinase anticancer drugs; sorafenib I, sunitinib II and erlotinib III (Figure 1). The ATP-binding site of EGFR-TK has the following features: Adenine binding region which is involved in two key hydrogen bonds formed by the interaction of $N 1$ and $N 6$ of adenine ring with the corresponding amino acids, many potent inhibitors usually utilize one of these hydrogen bonds. Additionally, there is a sugar pocket which is a hydrophilic region and a hydrophobic binding region though not utilized by ATP but they have significant role in binding affinity and inhibitor selectivity. Phosphate region which is largely solvent exposed and can be utilized for enhancing inhibitor selectivity. The majority of EGFR-TKIs do not exploit the sugar pocket and phosphate region. For a proper inhibitor to fit into the ATP active site, the basic structure usually constitutes (a) Central heteroaromatic ring system that contains at least one hydrogen bond acceptor, and it occupies the adenine binding region. (b) Terminal hydrophobic head that interacts with the hydrophobic binding region. (c) A spacer corresponding to the linker region between the adenine binding region and the hydrophobic binding region. (d) Hydrophobic tail which is directly attached to the heteroaromatic ring system and it occupies another hydrophobic binding region of the ATP- binding site of EGFR. [19-23] A design model for EGFR inhibitors structural features was constructed based on these analyses (Figure 1).

The current study uses this design model and fragment-based lead generation strategy in the design of new EGFR-TK inhibitors. Fragments are scaffolds that usually form part of drugs that are responsible of biological activities. These fragments are then combined to generate lead compounds [24, 25].
The central heteroatomic group used is pyrazole. The choice of pyrazole was done as pyrazole and its derivatives represent one of the most active classes of compounds, which exhibit broad spectrum of pharmacological activities such as antitumor [26, 27], anti-inflammatory [28], antitubercular [29], antibacterial [30], antifungal [31], antimalarial [32], antiviral [33], antioxidant[34], and analgesic properties [35] as well as antihyperglycemic activity [36].

Pyrazole is one of many significant scaffolds that have been studied and reported for their antitumor activity in vitro and in vivo against a broad range of cancers. Recently, a series of diarylpyrazole containing compounds (IV, Figure 1) synthesized and evaluated for their anticancer activity in vitro for five human cancer cell lines involving MCF-7, HaCaT, MDA-MB23, HepG2, and A549 have been reported as EGFR receptor inhibitors with low $\mathrm{IC}_{50 \text { s }}$ values [37].

Furthermore, Tao et al reported the activity of $1 H$-pyrazole-1carboxamide analogues as an EGFR/HER-2 tyrosine kinase inhibitor [38]. Additionally, several computational analyses for pyrazole derivatives have been reported, including quantitative structure activity relationship (QSAR) and molecular docking studies. Sunayana et al. studied the two-dimensional (2D) and three-dimensional (3D) group-based quantitative structure activity relationship (G-QSAR) for evaluating the activity of a set of thiazolyl-pyrazole derivatives as potent EGFR inhibitors [39]. $N$-benzyl group is employed as a spacer. $N$-benzyl has been reported in many biologically active compounds such as anticancer [40, 41] and antileishmanial activity [42]. Importantly, Yan Ren et al [43] reported the RIP1 kinase inhibitory activity with improved in vitro and in vivo profile of compound $\mathbf{V}$ with $\mathrm{IC}_{50}$ of $13 \mathrm{nM}$ (Figure 1). Additionally, the amide functionality is a common feature in small or complex synthetic or natural molecules. For example, proteins play a crucial role in all biological processes such as enzymatic catalysis (nearly all known enzymes are proteins) [44]. Moreover, amidation is extensively used in the synthesis of natural products, polymers, active pharmaceutical ingredients, and other biological molecules [45].

Furthermore, an in-depth analysis of the Comprehensive Medicinal Chemistry database revealed that the carboxamide group appears in more than $25 \%$ of known drugs [46, 47]. This can be expected, since carboxamides are neutral, stable and have both hydrogen-bond accepting and donating properties [44], which may participate in hydrogen bonding to the residues of amino acids in the active site of different enzymes. By doing so, the amide moiety can improve the binding site of the entire molecule.

Based on the aforementioned studies, the objective of this work is to collect the mentioned fragments in one lead compound as potential EGFR with potent anti-cancer activity. The potential inhibitors (5a-c, Figure 1) are designed by hybridizing both compound $\mathbf{I V}$ and $\mathbf{V}$ in one compact structure. It connects 1,5diarylpyrazole derivatives as the main heteroatomic fragment linked to $N$-benzyl hydrophobic head using a $N$-hydroxy carboxamide spacer. 


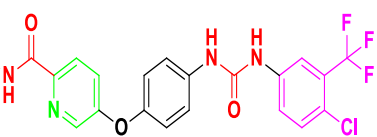

Sorafenib I

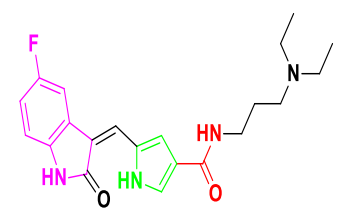

Sunitinib II

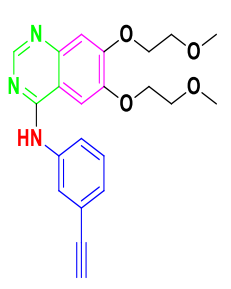

Erlotinib III

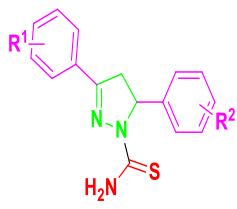

IV

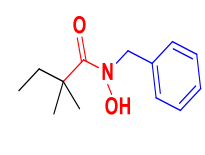

V

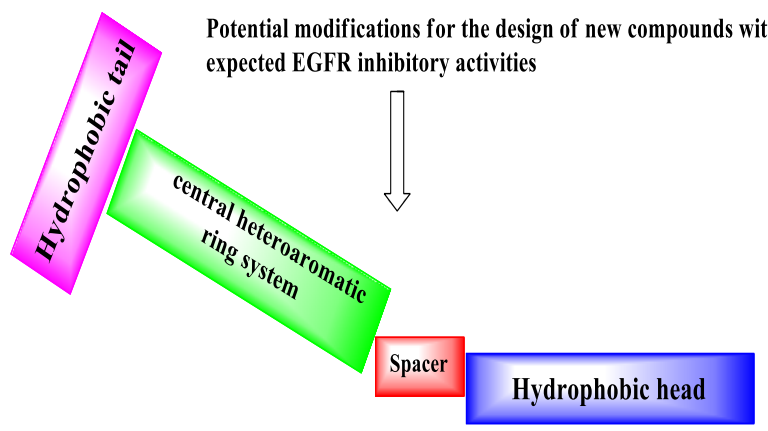

\section{Merging pharmacophores}

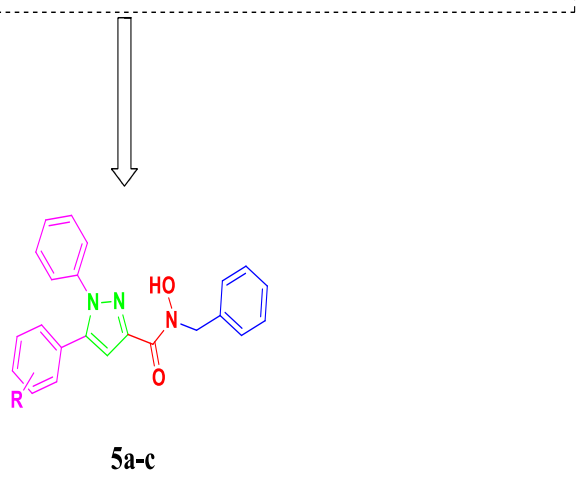

Figure 1. FDA approved EGFR inhibitor drugs I-III, reported EGFR inhibitor compound IV, reported RIP 1 kinase inhibitor compound $\mathbf{V}$, design model for expected EGFR inhibitor compounds and the designed structure of novel 1,5-diarylpyrazole carboxamide 5a-c as anticancer and EGFR inhibitors.

\section{Result and discussion}

\section{1. .Chemistry}

The synthetic protocol for compounds 5a-c is illustrated in Scheme 1. Claisen condensation [48] of substituted acetophenone derivative 1a-c with diethyl oxalate in the presence of sodium ethoxide $(\mathrm{NaOEt})$ in dried ethanol gave $\beta$-diketones derivatives 2a-c. $\beta$-Diketones derivatives 2a-c were heated at reflux for $6 \mathrm{~h}$ with phenylhydrazine in ethanol to afford ethyl 1,5-diaryl-1 $H$-pyrazole-3-carboxylates 3a-c. [49-51] Heating pyrazole derivatives 3a-c with potassium hydroxide at $60{ }^{\circ} \mathrm{C}$ for 4 h gave acid derivatives 4a-c [52].

The carboxylic acid derivatives $\mathbf{4 a - c}$ were then activated by 1-[3(dimethylamino)-propyl]-3-ethylcarbodiimide (EDCI) and 1hydroxybenztriazole (HOBT) as coupling agents in the presence of diisopropylethylamine. $\mathrm{HCl}$ as base at $0{ }^{\circ} \mathrm{C}$, the target compounds 5a-c synthesis were carried out by coupling with $N$ benzylhydroxylamine. $\mathrm{HCl}$ to obtain the novel products 5a-c (Scheme 1).
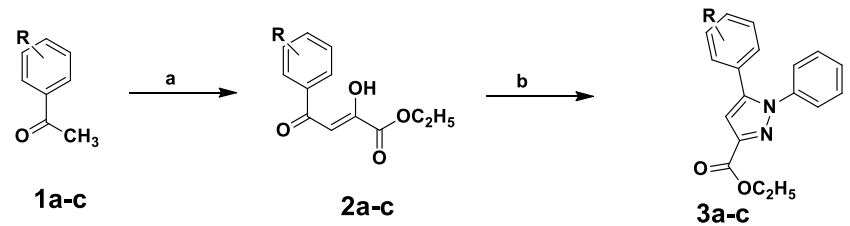

1-5a: $\mathrm{R}=4-\mathrm{CH}_{3}$

1-5b: $R=4-\mathrm{Cl}$

1-5c: $\mathrm{R}=3,4-\mathrm{di}-\mathrm{OCH}_{3}$
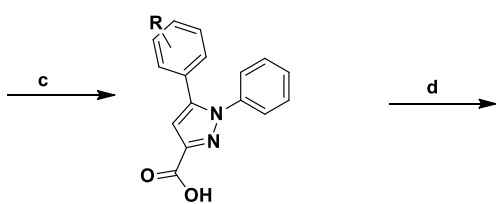

4a-c

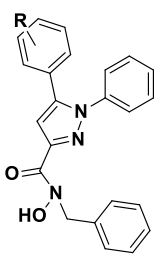

77-81\%

$5 a-c$

$69-71 \%$

Scheme 1. Synthesis of target compounds 5a-c. Reagent and condition: a) Diethyl oxalate, NaOEt, absolute ethanol, reflux $6 \mathrm{~h}$; b) phenylhydrazine, absolute ethanol, reflux $6 \mathrm{~h}$; c) $\mathrm{KOH}$ aq. (10-20\%), ethanol, $60{ }^{\circ} \mathrm{C}$ 4h; d) $\mathrm{N}$-benzylhydroxylamine. $\mathrm{HCl}$, dried DMF, DIPEA, EDCI/HOBT, stirring 12-18h, rt.

The prepared compounds were purified by subsequent column Chromatography. All targeted compounds were first reported and characterized by melting points, IR spectroscopy, ${ }^{1} \mathrm{H}$ NMR spectroscopy, ${ }^{13} \mathrm{C}$ NMR spectroscopy, and HRESI-MS, in accordance with their depicted structures.

The carboxamide derivatives 5a-c IR spectra characterized by the appearance of significant intense broad band at 3246-2764 $\mathrm{cm}^{-1}$ related to $(\mathrm{OH})$ group, the carbonyl group $(\mathrm{NC}=\mathrm{O})$ of carboxamide spacer appears at $1664-1589 \mathrm{~cm}^{-1}$ and $(\mathrm{C}=\mathrm{N})$ stretching band at $1585-1482 \mathrm{~cm}^{-1}$.

${ }^{1} \mathrm{H}$ NMR spectra of compounds 5a-c denoted by the appearance of three common signals at $\delta 4.89-5.58 \mathrm{ppm}$ related to $\left(\mathrm{CH}_{2}\right)$ protons, $\delta 6.81-7.39 \mathrm{ppm}$ related to pyrazole proton and singlet broad peaks of the amidic $(-\mathrm{N}-\mathrm{OH})$ proton at $\delta 8.12-8.76 \mathrm{ppm}$. Moreover, compound 5a showed a characteristic single peak at $\delta$ $2.34 \mathrm{ppm}$ which related to $\left(\mathrm{C}_{3}\right)$ protons at para position of the phenyl ring. Furthermore, the di-methoxy derivative $\mathbf{5 c}$ showed two singlet peaks at $\delta 3.93$ and $3.94 \mathrm{ppm}$ related to the dimethoxy protons. In addition, the doublet of doublet pattern in the aromatic proton's appears at region $\delta 7.26,7.42$ and 7.43, $7.49 \mathrm{ppm}$, respectively.

The ${ }^{13} \mathrm{C}$ NMR spectra of compounds 5a-c showed characteristic aromatic carbons at their expected absorption, also, the ${ }^{13} \mathrm{C} N \mathrm{NR}$ spectra of these derivatives showed three common characteristic 
signals at $\delta 36.61-36.75$ ppm related to $\left(\mathrm{CH}_{2}\right)$, at $\delta 110.46-110.70$ ppm due to pyrazole ring carbon and at $\delta 158.28-163.04$ ppm for $(\underline{\mathrm{C}}=\mathrm{O})$ of the amide bond. Moreover, compounds 5a showed characteristic signal at $\delta 20.87 \mathrm{ppm}$ related to $\left(\underline{\mathrm{CH}}_{3}\right)$ and compound $\mathbf{5 c}$ showed characteristic carbon signals at $\delta 56.02$ and $56.14 \mathrm{ppm}$ for methoxy group carbons.

The structures of compounds 5a-c were also ascertained by HRESI-MS. Molecular ion peaks $(\mathrm{m} / \mathrm{z})$ observed in positive ionization mode mostly bound to sodium atom and were consistent with their perceived molecular formulas. Compound 5a showed HRESI-MS $\mathrm{m} / \mathrm{z}$ of 406.1515 compared to that calculated for $[\mathrm{M}+\mathrm{Na}]^{+} \mathrm{C}_{24} \mathrm{H}_{21} \mathrm{~N}_{3} \mathrm{O}_{2}$ : 406.1531 .

\subsection{Biological evaluation}

\subsubsection{In vitro antiproliferative activities}

The synthesized compounds 5a-c were first screened at a single concentration of $100 \mu \mathrm{M}$ against five human cancer cell lines including colon cancer cell line (DLD), cervical cancer cell line (Hela), myelogenous leukemia cell line (K-562), pancreatic cancer cell line (SUIT) and liver cancer cell line (Hep-G2) using a standard water soluble tetrazolium-8 (WST-8) assay [53, 54] and daunorubicin was used as the reference compound. Screening results for each compound were represented as the growth inhibition percent as shown in Table $\mathbf{1}$ and Figure 2.

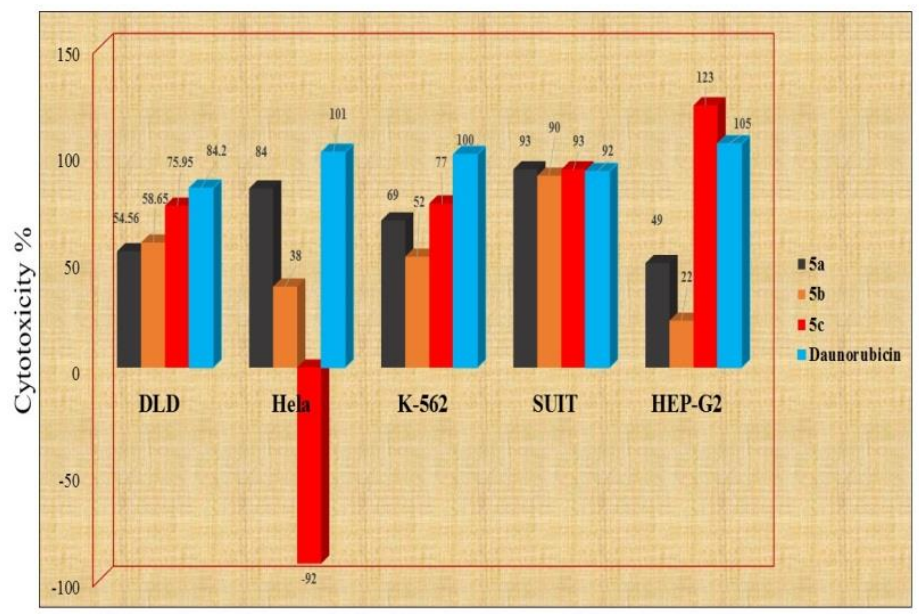

Cytotoxic activity at $100 \mu \mathrm{M}$ using daunorubicin as reference drug

Figure 2. Percentage growth inhibition of DLD, Hela, K-562, SUIT and Hep-G2 cell lines treated with compounds 5a-c or daunorubicin at concentration $100 \mu \mathrm{M}$.

Compound 5a with para-methyl group showed moderate to excellent cytotoxicity with growth inhibition percentages ranged from $49 \%$ to $93 \%$, the most significant cell growth inhibition was observed against pancreatic cancer cell line with $93 \%$ inhibition.

Compound 5b with para-Chloro group displayed weak to mild growth inhibition against four cancer cell lines with remarkable cytotoxicity toward pancreatic cancer cell line with growth inhibition percentage of $90 \%$.

Moreover, compound 5c with 3,4-di-methoxy group demonstrated significant antiproliferative activities against four cancer cell lines with growth inhibition percentages ranged from $75.95 \%$ to $123 \%$ with superior cytotoxicity than the positive control drug daunorubicin on pancreatic and hepatic cancer cell lines and similar growth inhibition with daunorubicin on both leukemia and colon cancer cell line (Table 1).

Table 1. In vitro antiproliferative activity of compounds $\mathbf{5 a - c .}$

\begin{tabular}{cccccc}
\hline \multicolumn{7}{c}{ \% cell growth inhibition at 100 $\mu \mathrm{M}$} \\
\hline Compound & DLD-1 & Hela & K-562 & SUIT & Hep.G2 \\
& & & & & \\
\hline $\mathbf{5 a}$ & $54.56 \%$ & $84 \%$ & $69 \%$ & $93 \%$ & $49 \%$ \\
$\mathbf{5 b}$ & $58.65 \%$ & $38 \%$ & $52 \%$ & $90 \%$ & $22 \%$ \\
$\mathbf{5 c}$ & $75.95 \%$ & $-92 \%$ & $77 \%$ & $93 \%$ & $123 \%$ \\
Daunorubicin & $84.2 \%$ & $101 \%$ & $100 \%$ & $92 \%$ & $105 \%$ \\
\hline
\end{tabular}

Consequently, Minimum concentration required to inhibit half of cell growth $\left(\mathrm{IC}_{50}\right)$ of compounds that revealed superior or comparable antiproliferative activity to the positive controls were further investigated towards human cancer cell lines: Hela, K-562 and Hep-G2. As depicted in Table 2, compound 5a exhibited excellent antiproliferative activities with $\mathrm{IC}_{50}$ values of $55 \mu \mathrm{M}$ and $16.40 \mu \mathrm{M}$ against Hela and K-562 cell lines, respectively. Moreover, compound $\mathbf{5 c}$ showed higher inhibitory activity against K-562 cell line comparable to daunorubicin with $\mathrm{IC}_{50}$ value of $17.20 \mu \mathrm{M}$ (daunorubicin $\mathrm{IC}_{50}=13.30 \mu \mathrm{M}$ ), on liver cancer cell line $\mathbf{5 c}$ displayed superior activity relative to daunorubicin itself with $\mathrm{IC}_{50}$ value of $21.20 \mu \mathrm{M}$ (daunorubicin $\mathrm{IC}_{50}=22 \mu \mathrm{M}$ ).

These data indicated that compound $\mathbf{5 c}(\mathbf{R}=3,4$-dimethoxy group) demonstrated the greatest active among this series and was considered for further evaluations.

Table 2. In vitro antiproliferative activity of compounds 5a-c as IC50 values.

\begin{tabular}{cccc}
\hline Compound & $\begin{array}{c}\text { Hela } \\
\mathbf{I C}_{\mathbf{5 0}}(\boldsymbol{\mu M})^{\mathrm{a}}\end{array}$ & $\begin{array}{c}\text { K-562 } \\
\mathbf{I C}_{\mathbf{5 0}}(\boldsymbol{\mu M})\end{array}$ & $\begin{array}{c}\text { HEP-G2 } \\
\mathbf{I C}_{\mathbf{5 0}}(\boldsymbol{\mu M})\end{array}$ \\
\hline $\mathbf{5 a}$ & 55 & 16.40 & $\mathrm{NT}$ \\
$\mathbf{5 c}$ & $\mathrm{NT}^{\mathrm{b}}$ & 17.20 & 21.20 \\
Daunorubicin & $\mathrm{ND}^{\mathrm{c}}$ & 13.30 & 22 \\
\hline
\end{tabular}

a: IC50 values are the mean of three senarate exneriments. b: not tested. c: not

\subsubsection{Molecular docking}

Molecular docking were conducted to support the potential role of the target compounds in inhibiting EGFR-TK and to better understand the binding interactions of the active antitumor agent 5a and 5c with EGFR-TK. Molecular docking studies were executed using the crystal structure of EGFR-TK in complex with erlotinib [55, 56] (PDB ID: 1M17). The molecular docking setup was validated by performing re-docking of erlotinib with the active site of EGFR-TK.

Compounds $\mathbf{5 a}$ and $\mathbf{5 c}$ could potentially fit in erlotinib binding site. They could form stable complexes with the active site of EGFR-TK with energy scores -7.01 and -7.73 , respectively 
compared to -7.63 for erlotinib, the standard ligand for EGFR enzyme.

Erlotinib showed two hydrogen bonds (3.38 and 3.17 ̊) towards ATP-binding site of EGFR with Gln767 and Met769 (Figure 3A). However, the most stable complex was observed with compound $\mathbf{5 c}$ showing three hydrogen bonding interactions, two formed between $\mathrm{N} 2$ of pyrazole ring and $\mathrm{O}$ atom of amide with Lys 721 residue and one bond between $\mathrm{OH}$ with Glu 738 residue with bond length 3.78, 2.77 and 3.28 A respectively, (Figure 3B). The obtained results proved that $\mathbf{5 c}$ can bind to the active site of EGFR-TK to a good extent, and it occupied the active site similarly to erlotinib (Figure 3); thus, it might exert its antitumor activity via EGFR-TK inhibition.

Furthermore, compound 5a displayed two hydrogen bonding towards EGFR binding site, one of them between $\mathrm{O}$ atom of carbonyl of amide with Lys721 residue and the second one is formed between and $\mathrm{OH}$ and Asp831 residue, as well as a hydrophobic interaction with Val702 residue with bond length 3.00, 3.30 and $4.18 \AA$, respectively (Figure 3C).

The presence of an electron donating groups in $\mathbf{5 c}$ might contribute to higher electron density on nitrogen atom thus contributing in the strength of the hydrogen bond formed with LYS $721\left(2.7 \mathrm{~A}^{\circ}\right)$ and this might explain the higher activity observed with $\mathbf{5 c}$.

Collectively, anti-cancer screening data together with docking study supported the design of compound $\mathbf{5 c}$ as a potential lead for the development of new pyrazole containing EGFR-TK inhibitors with potent cytotoxic effects.

\section{Experimental}

\subsection{Chemistry}

All chemicals used for the preparation of the target compounds are of analytical grade and used without further purification. Solvents were purified and freshly distilled prior to use according to the standard procedures. Column chromatographic separations were carried out on silica gel 60 N (63-210 mesh; Kanto chemical company, Tokyo, Japan). Precoated silica gel $60 \mathrm{~F}_{254}$ plates (E. Merck Darmstadt, Germany; $0.25 \mathrm{~mm}$ thick) were used for TLC analyses and the spots were detected by exposure to UV lamp at $\lambda 254 \mathrm{~nm}$. Melting points were determined using ATM02 (AS ONE, Tokyo, Japan) apparatus and are uncorrected, Faculty of engineering, Yamagata University, Yonezawa, Japan. IR spectra were recorded as $\mathrm{KBr}$ disks on Horiba FT-IR-720 spectrophotometer, Faculty of engineering, Yamagata University, Yonezawa, Japan. ${ }^{1} \mathrm{H}$ NMR (400 MHz) and ${ }^{13} \mathrm{C}-$ NMR (MHz) spectra were run on JNM-ECZ 400R/S1 MHz spectrometer, Faculty of engineering, Yamagata University, Yonezawa, Japan. TMS was used as an internal standard and $\mathrm{CDCl} 3$ or DMSO- $d 6$ as a solvent. Chemical shift $(\delta)$ values are expressed in parts per million (ppm). HRMS spectra (ESI-MS) were obtained using an AccuTOF JMS-T100LC (JEOL, Tokyo, Japan) and performed in Faculty of engineering, Yamagata University, Yonezawa, Japan.

\subsubsection{General procedure for the synthesis of $(Z)$-ethyl 2- hydroxy-4-oxo-4- substituted phenylbut-2-enoate derivatives (2a-c).}

A mixture of diethyl oxalate $(1.46 \mathrm{~g}, 10 \mathrm{mmol})$ and appropriate acetophenones $(10 \mathrm{mmol})$ was added drop wise to a stirred solution of freshly prepared NaOEt $(0.23 \mathrm{~g}, 10 \mathrm{mmol}$ sodium in $10 \mathrm{~mL}$ dried ethanol). The reaction mixture was heated under reflux for 2-3 h. After cooling the solvent was removed and the residue was taken up in water $(200 \mathrm{~mL})$ and acidified with concentrated $\mathrm{HCl}(1 \mathrm{~mL})$. The aqueous mixture was extracted with dichloromethane $(3 \times 50 \mathrm{~mL})$. The combined extracts were washed with brine $(100 \mathrm{~mL})$, dried over anhydrous $\mathrm{Na}_{2} \mathrm{SO}_{4}$, and concentrated. The obtained solid was crystallized from methanol to obtain pure compounds $\mathbf{2 a - c}[57,58]$.

$\begin{array}{lllll} & & \text { H-bond } & \text { Lys 721 } & 2.77 \\ \text { Erlotinib } & -7.63 & \text { H-bond } & \text { Gln 767 } & 3.38\end{array}$

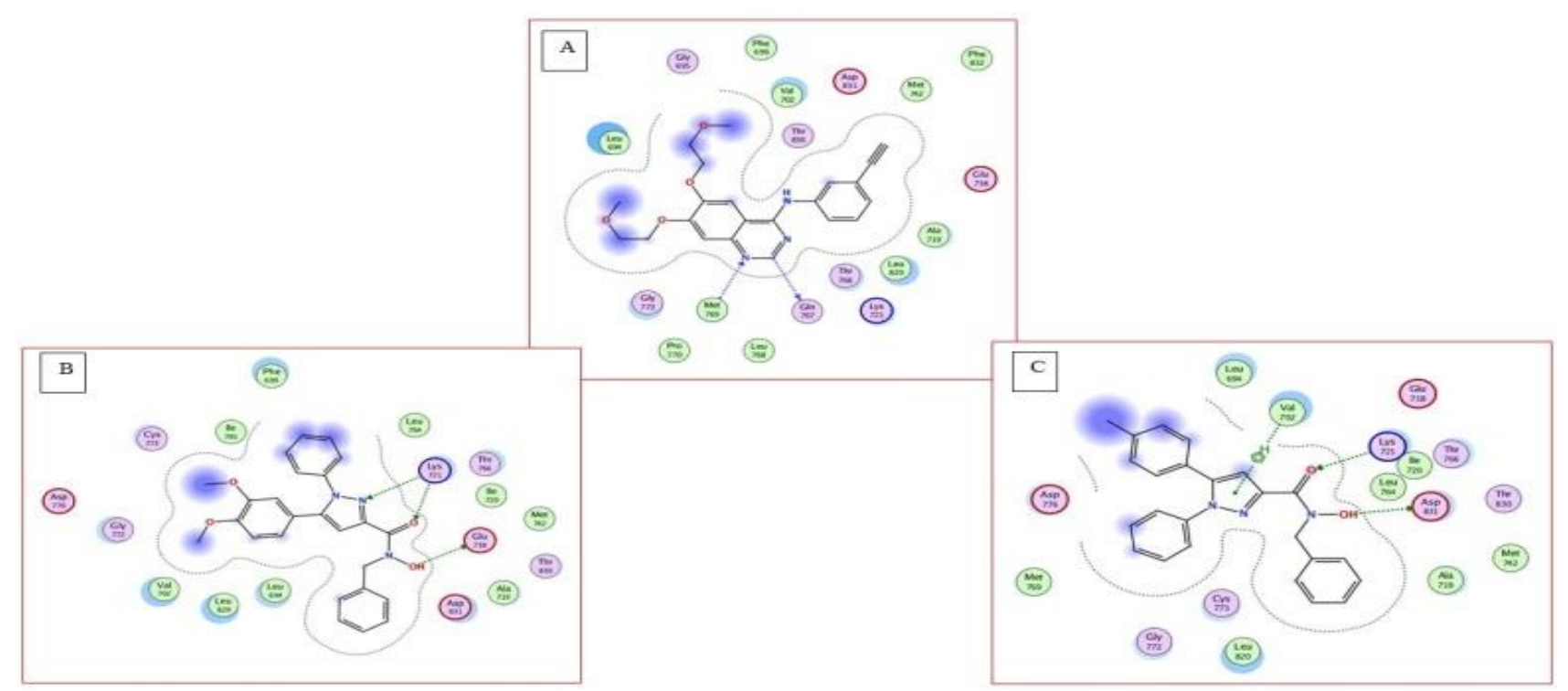

Figure 3. (A) 2D Diagram illustrating erlotinib docking pose interactions with the amino acids in the active site of EGFR-TK. (B) 2D Interaction of $\mathbf{5 c}$ with the active site of EGFR-TK. (C) 2D Interaction of $\mathbf{5 a}$ with the active site of EGFR-TK. 
3.1.1.1. (Z)-Ethyl 2-hydroxy-4-oxo-4-(p-tolyl)but-2-enoate (2a).

Yellow crystal (1.82 g, $78 \%$ yield); mp: $37-39{ }^{\circ} \mathrm{C}$ (reported: $37-$ $\left.39{ }^{\circ} \mathrm{C}\right)$ [58].

3.1.1.2. (Z)-Ethyl 4-(4-chlorophenyl)-2-hydroxy-4-oxobut-2enoate (2b).

Yellow crystal $\left(2.03 \mathrm{~g}, 80 \%\right.$ yield); mp: $190-191{ }^{\circ} \mathrm{C}$ (reported: 189-191 ${ }^{\circ}$ C) [59].

3.1.1.3. (Z)-Ethyl-4-(3,4-dimethoxyphenyl)-2-hydroxy-4oxobut-2-enoate (2c).

Yellow crystal (2.15 g, $77 \%$ yield); mp: 99-100 'C (reported: 99$\left.101{ }^{\circ} \mathrm{C}\right)[60]$.

3.1.2. General procedure for the synthesis of ethyl substituted 1,5- diphenyl-1H-pyrazole-3-carboxylate derivatives (3a-c).

A suitable diketoester $\mathbf{2 a - c}(10 \mathrm{mmol})$ was dissolved in ethanol $(50 \mathrm{~mL})$ by heating and then appropriate hydrazine $(10 \mathrm{mmol})$ was added onto the mixture. The reaction process was monitored by TLC using dichloromethane: methanol (9.5:0.5) solvent system. The orange color reaction mixture was refluxed for $6 \mathrm{~h}$. The content of the reaction mixture was concentrated to half of its volume under vacuum and then kept at room temperature. The formed precipitate was filtered, dried and crystallized from ethanol. All spectral data confirmed the chemical structure of the compounds as reported [61].

3.1.2.1.Ethyl 1-phenyl-5-(p-tolyl)-1H-pyrazole-3-carboxylate (3a).

White solid (2.32 g, $76 \%$ yield); mp: $84-86{ }^{\circ} \mathrm{C}$ (reported: $84-86$ $\left.{ }^{\circ} \mathrm{C}\right)$ [62].

3.1.2.2.Ethyl 5-(4-chlorophenyl)-1-phenyl-1H-pyrazole-3carboxylate (3b).

Yellowish solid (2.34 g, $72 \%$ yield); mp: $94{ }^{\circ} \mathrm{C}$ (reported: $94-95$ $\left.{ }^{\circ} \mathrm{C}\right)[52,63]$.

3.1.2.3.Ethyl5-(3,4-dimethoxyphenyl)-1-phenyl-1H-pyrazole3-carboxylate (3c).

Brownish powder $\left(2.74 \mathrm{~g}, 78 \%\right.$ yield); mp: $177-179{ }^{\circ} \mathrm{C}$ (reported: $\left.177-178^{\circ} \mathrm{C}\right)$ [57].

\subsubsection{General procedure for the synthesis of substituted 1,5-} diphenyl-1H-pyrazole-3-carboxylic acids (4a-c).

To a solution of compounds 3a-c (4 mmol) in methanol $(20 \mathrm{~mL})$, potassium hydroxide $(\mathrm{KOH})(20 \%, 10 \mathrm{~mL})$ was added with a few drops of distilled water and the mixture was stirred at $60{ }^{\circ} \mathrm{C}$ for 4 h. The mixture was allowed to cool, poured into water and acidified with the hydrochloric acid solution $(1 \mathrm{M})$ to $\mathrm{PH}=3$. The aqueous solution was extracted using ethyl acetate $(3 \times 50 \mathrm{~mL})$ and the organic layer was collected, dried over anhydrous $\mathrm{Na}_{2} \mathrm{SO}_{4}$. Solvent was evaporated under reduced pressure to afford 4a-c [64].

3.1.3.1. 1-Phenyl-5-(p-tolyl)-1H-pyrazole-3-carboxylic acid (4a).

Yellowish solid (0.89 g, $80 \%$ yield); mp: 171-173 ${ }^{\circ} \mathrm{C}$ [64].

3.1.3.2. 5-(4-Chlorophenyl)-1-phenyl-1H-pyrazole-3carboxylic acid (4b).

White solid (0.96 g, $81 \%$ yield); mp: $>300{ }^{\circ} \mathrm{C}$ (reported: >300 $\left.{ }^{\circ} \mathrm{C}\right)[52]$.

3.1.3.3. 5-(3,4-Dimethoxyphenyl)-1-phenyl-1H-pyrazole-3carboxylic acid (4c). brown powder, $(0.28 \mathrm{~g}, 77 \%$ yield $)$; mp: $213-214{ }^{\circ} \mathrm{C} ;{ }^{1} \mathrm{H}$ NMR $\left(400 \mathrm{MHz}, \mathrm{DMSO}-d_{6}\right) \delta 3.77\left(\mathrm{~s}, 3 \mathrm{H}, \mathrm{OCH}_{3}\right), 3.79$ (s, 3H, $\left.\mathrm{OCH}_{3}\right)$, 6.68-6.94 (m, 3H, Ar- $\mathrm{H}), 7.39$ (s, 1H, pyrazole-H), 7.52-7.94 (m, $5 \mathrm{H}, \mathrm{Ar}-\underline{\mathrm{H}}) ;{ }^{13} \mathrm{C}$ NMR $\left(100 \mathrm{MHz}, \mathrm{DMSO}-d_{6}\right) \delta$ 56.12, 56.23, 110.45, 115.26, 120.40, 122.05, 125.40, 126.47, 127.45, 128.76, $130.71,142.55,144.09,145.81,160.36,163.60 ;$ ESI-MS m/z $[\mathrm{M}+\mathrm{H}]^{+}$for $\mathrm{C}_{18} \mathrm{H}_{16} \mathrm{~N}_{2} \mathrm{O}_{4}: 325.256$.

3.1.4. General procedure for the synthesis of N-benzyl-Nhydroxy-1-aryl-5-(substituted phenyl)-1H-pyrazole-3carboxamide (5a-c).

A mixture of 1,5-diphenyl pyrazole-3-carboxylic acids 4a-c (1 mmol), 1-[3-(dimethylamino)-propyl]-3-ethylcarbodiimide (EDCI, $0.286 \mathrm{~g}, 1.5 \mathrm{mmol}$ ), 1-hydroxybenztriazole (HOBT, 0.20 $\mathrm{g}, 1.5 \mathrm{mmol}$.), and diisopropylethylamine. $\mathrm{HCl}$ (DIPEA, $0.258 \mathrm{~g}$, $2 \mathrm{mmol})$ in dried DMF $(10 \mathrm{~mL})$ was stirred for $10 \mathrm{~min}$ at $\mathrm{rt}$ before addition of $N$-benzylhydroxylamine. $\mathrm{HCl}(0.19 \mathrm{~g}, 1.2 \mathrm{mmol})$. The resulting reaction mixture was stirred for $12-18 \mathrm{~h}$ at $\mathrm{rt}$. The solvent was evaporated under reduced pressure, the residue was extracted ethyl acetate $(2 \times 50 \mathrm{~mL})$, washed with $5 \% \mathrm{HCl}$, saturated $\mathrm{NaHCO}_{3}(10 \mathrm{~mL})$ solution, brine $(10 \mathrm{~mL})$, dried over anhydrous $\mathrm{MgSO}_{4}$, and evaporated under reduced pressure to give a crude product which was purified by silica gel column chromatography using mixture of chloroform and methanol (99.5: 0.5) as eluent.

3.1.4.1. $\quad N$-Benzyl- $N$-hydroxy-1-phenyl-5-(p-tolyl)-1Hpyrazole-3-carboxamide (5a).

Brownish solid, $(0.27 \mathrm{~g}, 71 \%$ yield $)$; $\mathrm{mp}: 151-152^{\circ} \mathrm{C}$; IR $\left(\mathrm{v}, \mathrm{cm}^{-}\right.$ $\left.{ }^{1}\right)$ : 3246-2764 (br, OH), $1634(\mathrm{C}=\mathrm{O}$, amide), $1491(\mathrm{C}=\mathrm{N}), 1412$ $(\mathrm{C}=\mathrm{C}) ;{ }^{1} \mathrm{H}$ NMR $\left(400 \mathrm{MHz}, \mathrm{CDCl}_{3}\right) \delta 2.34\left(\mathrm{~s}, 3 \mathrm{H}, \mathrm{CH}_{3}\right), 5.58(\mathrm{~s}$, $\left.2 \mathrm{H}, \underline{\mathrm{C}}_{2}\right), 7.06-7.15$ (m, 6H, 5Ar- $\underline{\mathrm{H}}$, pyrazole- $\left.\underline{\mathrm{H}}\right), 7.26$ (d, $2 \mathrm{H}, J$ $=8.00 \mathrm{~Hz}, \operatorname{Ar}-\underline{\mathrm{H}}), 7.30-7.35(\mathrm{~m}, 5 \mathrm{H}, \mathrm{Ar}-\underline{\mathrm{H}}), 7.43(\mathrm{~d}, 2 \mathrm{H}, J=8.00$ $\mathrm{Hz}, \mathrm{Ar}-\underline{\mathrm{H}}), 8.7 \overline{6}$ (s, br, $1 \mathrm{H}, \mathrm{OH}) ;{ }^{13} \mathrm{C} \mathrm{NMR}\left(100 \mathrm{MHz}, \mathrm{CDCl}_{3}\right) \delta$ 20.87, 36.61, 110.59, 124.90, 125.55, 125.70, 126.61, 127.37, 127.84, 128.36, 128.77, 128.97, 129.46, 136.18, 139.02, 139.64, 144.64, 158.28; HRESI-MS m/z calcd for $[\mathrm{M}+\mathrm{Na}]^{+} \mathrm{C}_{24} \mathrm{H}_{21} \mathrm{~N}_{3} \mathrm{O}_{2}$ : 406.1531, found: 406.1515 .

3.1.4.2. $\quad N$-Benzyl-5-(4-chlorophenyl)- $N$-hydroxy-1-phenyl$1 \mathrm{H}$-pyrazole-3-carboxamide (5b).

Brownish solid, $(0.28 \mathrm{~g}, 69 \%$ yield $)$; mp: $121-122^{\circ} \mathrm{C}$; IR $\left(\mathrm{v}, \mathrm{cm}^{-}\right.$ $\left.{ }^{1}\right)$ : 3023-2759 (br, OH), 1589 (C=O, amide), $1482(\mathrm{C}=\mathrm{N}), 1353$ $(\mathrm{C}=\mathrm{C}) ;{ }^{1} \mathrm{H}$ NMR $\left(400 \mathrm{MHz}, \mathrm{CDCl}_{3}\right) \delta 5.57\left(\mathrm{~s}, 2 \mathrm{H}, \mathrm{CH}_{2}\right), 7.12(\mathrm{~s}$, $1 \mathrm{H}$, pyrazole- $\underline{\mathrm{H}})$ 7.23-7.36 (m, 10H, Ar- $\underline{\mathrm{H}}), 7.42(\mathrm{~d}, \overline{2 \mathrm{H}}, J=8.00$ $\mathrm{Hz}, \mathrm{Ar}-\underline{\mathrm{H}}), 7.49$ (d, $2 \mathrm{H}, J=8.00 \mathrm{~Hz}, \mathrm{Ar}-\underline{\mathrm{H}}), 8.10$ (s br, $1 \mathrm{H}, \mathrm{OH})$; ${ }^{13} \mathrm{C} \mathrm{NMR}\left(100 \mathrm{MHz}, \mathrm{CDCl}_{3}\right) \delta 36.75,110.70,121.05,124.36$, 125.76, 127.48, 128.62, 130.12, 131.39, 131.98, 132.85, 134.91, 136.58, 139.05, 143.62, 150.44, 162.67; HRESI-MS m/z calcd for $[\mathrm{M}+\mathrm{Na}]^{+} \mathrm{C}_{23} \mathrm{H}_{18} \mathrm{ClN}_{3} \mathrm{O}_{2}$ : 426.0985, found: 426.0956 .

3.1.4.3. $\quad N$-Benzyl-5-(3,4-dimethoxyphenyl)- $N$-hydroxy-1phenyl-1 $H$-pyrazole-3-carboxamide $(5 \mathrm{c})$.

Brownish solid, $(0.30 \mathrm{~g}, 70 \%$ yield $)$; mp: $62-63{ }^{\circ} \mathrm{C}$; IR $\left(v, \mathrm{~cm}^{-1}\right)$ : 2917-2832 (OH), $1664(\mathrm{C}=\mathrm{O}$, amide), $1585(\mathrm{C}=\mathrm{N}), 1498(\mathrm{C}=\mathrm{C})$, ${ }^{1} \mathrm{H}$ NMR (400 MHz, $\left.\mathrm{CDCl}_{3}\right) \delta 3.93\left(\mathrm{~s}, 3 \mathrm{H}, \mathrm{OC}_{3}\right), 3.94(\mathrm{~s}, 3 \mathrm{H}$, $\left.\mathrm{OCH}_{3}\right), 4.89$ (s, $\left.2 \mathrm{H}, \underline{\mathrm{CH}}_{2}\right), 6.81$ (s, 1H, pyrazole- $\left.\underline{\mathrm{H}}\right), 6.86-6.90$ (m, 1H, Ar- $\underline{\mathrm{H}}), 7.19-7.41$ (m, 10H, Ar- $\underline{\mathrm{H}}), 7.49-7.58$ (m, 2H, Ar$\underline{\mathrm{H}}), 8.12$ (s br, $1 \mathrm{H}, \mathrm{OH}) ;{ }^{13} \mathrm{C} \mathrm{NMR}\left(100 \mathrm{MHz}, \mathrm{CDCl}_{3}\right) \delta 36.62$, 
$56.02,56.14,108.88,110.46,111.88,120.94,121.60,123.04$, $124.80,125.94,126.64,127.80,129.14,130.47,132.07,135.89$, 144.29, 147.73, 149.26, 153.08, 163.04; HRESI-MS m/z calcd for $[\mathrm{M}+\mathrm{Na}]^{+} \mathrm{C}_{25} \mathrm{H}_{23} \mathrm{~N}_{3} \mathrm{O}_{4}$ : 452.1586, found: 452.1570 .

\subsection{Biological Activities Screening}

\subsubsection{In vitro antiproliferative activities}

The current synthesized compounds have been tested for their anticancer activities against five different cancer cell lines; DLD, Hela, K-562, SUIT and Hep-G2 and daunorubicin was used as the reference compound by a standard water-soluble tetrazolium8 (WST-8) assay, the five cells were maintained in a suspension culture, (DMEM for Hela, SUIT and Hep-G2 or PRIM for DLD and K-562), supplemented with 5\% FBS (Fetal Bovine Serum) containing $1 \%$ of a penicillin-streptomycin (1:1) mixture. A 100 $\mu \mathrm{L}$ aliquot of cells (10000 cells $/ \mathrm{mL})$ was added to a 96 well plate and incubated for $24 \mathrm{~h}$ at $37^{\circ} \mathrm{C}$ in a humidified incubator containing $5 \% \mathrm{CO}_{2}$ in air. After $24 \mathrm{~h}$, a $10 \mu \mathrm{L}$ aliquot of compound (concentrations varying in the range of $10-150 \mu \mathrm{M}$ ) was added to each of the 96 wells and incubated for $24 \mathrm{~h}$. Then A $10 \mu \mathrm{L}$ WST-8 solution (mixture of WST-8 and 1-Methoxy PMS) was added to each well and the incubation continued for 3 $\mathrm{h}$. The visible absorbance at $450 \mathrm{~nm}$ and $630 \mathrm{~nm}$ as the reference wavelength of each well was quantified using MTP-310 absorbance microplate reader. Daunorubicin was used as a positive control. The results of cytotoxicity were reported as growth inhibition percentages and as $\mathrm{IC}_{50}$ values $[53,54]$.

\subsubsection{Molecular docking}

The crystal structure of EGFR enzyme ((PDB ID: 1M17; $2.6 \AA$ ) was downloaded from the Protein Data Bank at https://www.rcsb.org. The structure was identified by X-ray diffraction as the crystal structure of EGFR in complex with erlotinib with resolution of $2.6 \AA$.

The ligand was removed and the active site was selected using site finder. Hydrogen atoms were added and the structure was subjected to automatic correction to check for any errors in the atom's connection and type. Both the potential and charges were fixed and dummy atoms were added instead of ligand atoms.

The 2D structures of the target compounds and erlotinib were built using builder interface. Energy minimization was run to a RMSD gradient of $0.01 \mathrm{kcal} / \mathrm{mol}$ and $0.1 \AA$. A database was built using these 2D structures and saved as a MDB file.

The dock tool of Molecular Operating Environment (MOE) 2019.0102 software was used for fitting of the isolated compounds' database into the active site of EGFR-TK enzyme. Docking site was selected as dummy atoms, alpha triangle as the placement methodology, and London $\mathrm{dG}$ as the scoring methodology. The docking process was run followed by evaluation for poses. Poses with the highest energy scores and best ligand-enzyme interactions were selected and recorded [55, 56].

\section{Conclusion}

This research reported the use of fragment-based drug design in the development of a pyrazole carrying EGFR inhibitor. 1,5Diarylpyrazole were synthesized using simple synthetic procedure. Three compounds were synthesized and evaluated for in vitro against a panel of five cancer cell lines, DLD, Hela, K562, SIUT and HepG-2. The anticancer activity revealed that compound 5c displayed the most active member among this series against four cancer cell lines with cytotoxicity percentages ranged from $75.95 \%$ to $123 \%$ with superior cytotoxicity than daunorubicin on SUIT and Hep-G2 cancer cell lines. Also, compound $\mathbf{5 c}$ showed higher inhibitory activity against K-562 cell line comparable to daunorubicin with $\mathrm{IC}_{50}$ value of $17.20 \mu \mathrm{M}$ on Hep-G2 cancer cell line and displayed outstanding activity relative to daunorubicin itself with $\mathrm{IC}_{50}$ value of $21.20 \mu \mathrm{M}$ (daunorubicin $\mathrm{IC}_{50}=22 \mu \mathrm{M}$ ). Moreover, the docking studies were also performed to suggest possible explanation of the results obtained from antiproliferative activities which confirmed the exact binding interactions of $\mathbf{5} \mathbf{c}$ with the active site of EGFR-TK. Based on that, the most active compound $\mathbf{5} \mathbf{c}$ could be used as a lead for future design, optimization and investigation for further evaluations and to produce more effective analogs as potent anticancer agents.

\section{REFERENCES}

[1] Heron M, Anderson RN. Changes in the leading cause of death: recent patterns in heart disease and cancer mortality. NCHS data brief. 2016;254.

[2] Miller KD, Goding Sauer A, Ortiz AP, Fedewa SA, Pinheiro PS, TortoleroLuna G, et al. Cancer statistics for hispanics/latinos, 2018. CA: A Cancer Journal for Clinicians. 2018;68(6):425-45.

[3] Hulvat MC. Cancer Incidence and Trends. Surgical Oncology for the General Surgeon, an Issue of Surgical Clinics E-Book. 2020:469.

[4] Feng L-S. Development and Advances of Drugs for Cancer Theranostics. Current Topics in Medicinal Chemistry. 2020;20(16):1440-.

[5] Yang M, Liu H, Zhang Y, Wang X, Xu Z. Moxifloxacin-isatin Hybrids Tethered by 1, 2, 3-triazole and their Anticancer Activities. Current topics in medicinal chemistry. 2020;20(16):1461-7.

[6] Feng L-S. Development and Advances of Drugs for Cancer TheranosticsPART-II. Current Topics in Medicinal Chemistry. 2020;20(21):1910-.

[7] Goffin JR, Zbuk K. Epidermal growth factor receptor: pathway, therapies, and pipeline. Clinical therapeutics. 2013;35(9):1282-303.

[8] Arteaga CL. Epidermal growth factor receptor dependence in human tumors more than just expression? The oncologist. 2002;7:31-9.

[9] Lee H, Seo A, Kim E, Jang M, Kim Y, Kim J, et al. Prognostic and predictive values of EGFR overexpression and EGFR copy number alteration in HER2positive breast cancer. British journal of cancer. 2015;112(1):103-11.

[10] Suzuki M, Wada H, Yoshino M, Tian L, Shigematsu H, Suzuki H, et al. Molecular characterization of chronic obstructive pulmonary disease-related nonsmall cell lung cancer through aberrant methylation and alterations of EGFR signaling. Annals of surgical oncology. 2010;17(3):878-88.

[11] Lynch TJ, Bell DW, Sordella R, Gurubhagavatula S, Okimoto RA, Brannigan BW, et al. Activating mutations in the epidermal growth factor receptor underlying responsiveness of non-small-cell lung cancer to gefitinib. New England Journal of Medicine. 2004;350(21):2129-39.

[12] Pao W, Chmielecki J. Rational, biologically based treatment of EGFRmutant non-small-cell lung cancer. Nature Reviews Cancer. 2010;10(11):760-74 [13] Wilhelm S, Carter C, Lynch M, Lowinger T, Dumas J, Smith RA, et al. Discovery and development of sorafenib: a multikinase inhibitor for treating cancer. Nature reviews Drug discovery. 2006;5(10):835-44.

[14] Liu B, Diaz Arguello OA, Chen D, Chen S, Saber A, Haisma HJ. CRISPRmediated ablation of overexpressed EGFR in combination with sunitinib significantly suppresses renal cell carcinoma proliferation. Plos one. 2020;15(5):e0232985.

[15] Johnson ML, Helena AY, Hart EM, Weitner BB, Rademaker AW, Patel JD, et al. Phase I/II study of HSP90 inhibitor AUY922 and erlotinib for EGFR-mutant lung cancer with acquired resistance to epidermal growth factor receptor tyrosine kinase inhibitors. Journal of Clinical Oncology. 2015;33(15):1666.

[16] Johnston S, Leary A. Lapatinib: a novel EGFR/HER2 tyrosine kinase inhibitor for cancer. Drugs Today (Barc). 2006;42(7):441-53.

[17] Schiffer E, Housset C, Cacheux W, Wendum D, Desbois-Mouthon C, Rey $\mathrm{C}$, et al. Gefitinib, an EGFR inhibitor, prevents hepatocellular carcinoma development in the rat liver with cirrhosis. Hepatology. 2005;41(2):307-14.

[18] Brown BP, Zhang Y-K, Westover D, Yan Y, Qiao H, Huang V, et al. Ontarget resistance to the mutant-selective EGFR inhibitor osimertinib can develop in an allele-specific manner dependent on the original EGFR-activating mutation. Clinical Cancer Research. 2019;25(11):3341-51.

[19] Fabbro D, Ruetz S, Buchdunger E, Cowan-Jacob SW, Fendrich G, Liebetanz $\mathrm{J}$, et al. Protein kinases as targets for anticancer agents: from inhibitors to useful drugs. Pharmacology \& therapeutics. 2002;93(2-3):79-98.

[20] Zhao Z, Wu H, Wang L, Liu Y, Knapp S, Liu Q, et al. Exploration of type II binding mode: A privileged approach for kinase inhibitor focused drug discovery? ACS chemical biology. 2014;9(6):1230-41. 
[21] Mowafy S, Galanis A, Doctor ZM, Paranal RM, Lasheen DS, Farag NA, et al. Toward discovery of mutant EGFR inhibitors; Design, synthesis and in vitro biological evaluation of potent 4-arylamino-6-ureido and thioureido-quinazoline derivatives. Bioorganic \& medicinal chemistry. 2016;24(16):3501-12.

[22] Furet P, Caravatti G, Lydon N, Priestle JP, Sowadski JM, Trinks U, et al. Modelling study of protein kinase inhibitors: binding mode of staurosporine and origin of the selectivity of CGP 52411. Journal of Computer-Aided Molecular Design. 1995;9(6):465-72

[23] Warda ET, Shehata IA, El-Ashmawy MB, El-Gohary NS. New series of isoxazole derivatives targeting EGFR-TK: Synthesis, molecular modeling and antitumor evaluation. Bioorganic \& Medicinal Chemistry. 2020;28(21):115674.

[24] Hajduk PJ, Greer J. A decade of fragment-based drug design: strategic advances and lessons learned. Nature reviews Drug discovery. 2007;6(3):211-9.

[25] Kumar A, Voet A, Zhang K. Fragment based drug design: from experimental to computational approaches. Current medicinal chemistry. 2012;19(30):512847.

[26] Balbi A, Anzaldi M, Macciò C, Aiello C, Mazzei M, Gangemi R, et al. Synthesis and biological evaluation of novel pyrazole derivatives with anticancer activity. European Journal of Medicinal Chemistry. 2011;46(11):5293-309.

[27] Bouabdallah I, M'Barek LA, Zyad A, Ramdani A, Zidane I, Melhaoui A. Anticancer effect of three pyrazole derivatives. Natural product research. 2006;20(11):1024-30.

[28] Bekhit AA, Abdel-Aziem T. Design, synthesis and biological evaluation of some pyrazole derivatives as anti-inflammatory-antimicrobial agents. Bioorganic \& medicinal chemistry. 2004;12(8):1935-45

[29] Pathak RB, Chovatia P, Parekh H. Synthesis, antitubercular and antimicrobial evaluation of 3-(4-chlorophenyl)-4-substituted pyrazole derivatives. Bioorganic \& medicinal chemistry letters. 2012;22(15):5129-33.

[30] Tanitame A, Oyamada Y, Ofuji K, Fujimoto M, Iwai N, Hiyama Y, et al. Synthesis and antibacterial activity of a novel series of potent DNA gyrase inhibitors. Pyrazole derivatives. Journal of medicinal chemistry. 2004;47(14):3693-6.

[31] Zhang CY, Liu XH, Wang BL, Wang SH, Li ZM. Synthesis and Antifungal Activities of New Pyrazole Derivatives via 1, 3-dipolar Cycloaddition Reaction. Chemical biology \& drug design. 2010;75(5):489-93.

[32] Bekhit AA, Hymete A, Asfaw H, Bekhit AEDA. Synthesis and Biological Evaluation of Some Pyrazole Derivatives as Anti-Malarial Agents. Archiv der Pharmazie. 2012;345(2):147-54

[33] Ouyang G, Cai X-J, Chen Z, Song B-A, Bhadury PS, Yang S, et al. Synthesis and antiviral activities of pyrazole derivatives containing an oxime moiety. Journal of agricultural and food chemistry. 2008;56(21):10160-7.

[34] Viveka S, Madhu LN, Nagaraja GK. Synthesis of new pyrazole derivatives via multicomponent reaction and evaluation of their antimicrobial and antioxidant activities. Monatshefte für Chemie-Chemical Monthly. 2015;146(9):1547-55.

[35] El Shehry M, Ewies E, Zayed E. Synthesis of New Pyrazole Derivatives, Their Anti-Inflammatory and Analgesic Activities, and Molecular Docking Studies. Russian Journal of General Chemistry. 2019;89(3):492-8.

[36] Kenchappa R, Bodke YD, Chandrashekar A, Sindhe MA, Peethambar S. Synthesis of coumarin derivatives containing pyrazole and indenone rings as potent antioxidant and antihyperglycemic agents. Arabian Journal of Chemistry. 2017;10:S3895-S906

[37] Akhtar MJ, Khan AA, Ali Z, Dewangan RP, Rafi M, Hassan MQ, et al. Synthesis of stable benzimidazole derivatives bearing pyrazole as anticancer and EGFR receptor inhibitors. Bioorganic Chemistry. 2018;78:158-69.

[38] Tao X-X, Duan Y-T, Chen L-W, Tang D-J, Yang M-R, Wang P-F, et al. Design, synthesis and biological evaluation of pyrazolyl-nitroimidazole derivatives as potential EGFR/HER-2 kinase inhibitors. Bioorganic \& Medicinal Chemistry Letters. 2016;26(2):677-83.

[39] Sunayana G, Shashikant B, Sandeep W. 2D, 3D, G-QSAR and docking studies of thiazolyl-pyrazoline analogues as potent (epidermal growth factor receptor-tyrosine kinase) EGFR-TK inhibitors. Letters in Drug Design \& Discovery. 2017;14(11):1228-38.

[40] Klunda T, Šesták S, Kóňa J, Poláková M. Synthesis of N-benzyl substituted 1, 4-imino-1-lyxitols with a basic functional group as selective inhibitors of Golgi $\alpha$-mannosidase IIb. Bioorganic Chemistry. 2019;83:424-31.

[41] Hu Q, Wang C, Xiang Q, Wang R, Zhang C, Zhang M, et al. Discovery and optimization of novel N-benzyl-3, 6-dimethylbenzo [d] isoxazol-5-amine derivatives as potent and selective TRIM24 bromodomain inhibitors with potential anti-cancer activities. Bioorganic Chemistry. 2020;94:103424.

[42] Nieto-Meneses R, Castillo R, Hernández-Campos A, Maldonado-Rangel A, Matius-Ruiz JB, Trejo-Soto PJ, et al. In vitro activity of new N-benzyl-1Hbenzimidazol-2-amine derivatives against cutaneous, mucocutaneous and visceral Leishmania species. Experimental parasitology. 2018;184:82-9.

[43] Ren Y, Su Y, Sun L, He S, Meng L, Liao D, et al. Discovery of a highly potent, selective, and metabolically stable inhibitor of receptor-interacting protein 1 (RIP1) for the treatment of systemic inflammatory response syndrome. Journal of medicinal chemistry. 2017;60(3):972-86.

[44] Montalbetti CA, Falque V. Amide bond formation and peptide coupling. Tetrahedron. 2005;61(46):10827-52
[45] Chandra J, Manne SR, Mondal S, Mandal B. (E)-Ethyl-2-cyano-2-(((2, 4, 6trichlorobenzoyl) oxy) imino) acetate: A Modified Yamaguchi Reagent for Enantioselective Esterification, Thioesterification, Amidation, and Peptide Synthesis. ACS omega. 2018;3(6):6120-33.

[46] Pattabiraman VR, Bode JW. Rethinking amide bond synthesis. Nature. 2011;480(7378):471-9.

[47] Liu X, Lin L, Feng X. Amide-based bifunctional organocatalysts in asymmetric reactions. Chemical Communications. 2009(41):6145-58.

[48] Sidique S, Ardecky R, Su Y, Narisawa S, Brown B, Millán JL, et al. Design and synthesis of pyrazole derivatives as potent and selective inhibitors of tissuenonspecific alkaline phosphatase (TNAP). Bioorganic \& medicinal chemistry letters. 2009;19(1):222-5

[49] Bechmann N, Kniess T, Köckerling M, Pigorsch A, Steinbach J, Pietzsch J. Novel (pyrazolyl) benzenesulfonamides with a nitric oxide-releasing moiety as selective cyclooxygenase-2 inhibitors. Bioorganic \& medicinal chemistry letters. 2015;25(16):3295-300.

[50] Karrouchi K, Radi S, Ramli Y, Taoufik J, Mabkhot YN, Al-Aizari FA. Synthesis and pharmacological activities of pyrazole derivatives: a review. Molecules. 2018;23(1):134.

[51] Knorr L. Einwirkung von acetessigester auf phenylhydrazin. Berichte der deutschen chemischen Gesellschaft. 1883;16(2):2597-9.

[52] Aghazadeh Tabrizi M, Baraldi PG, Baraldi S, Ruggiero E, De Stefano L, Rizzolio F, et al. Discovery of 1,5-diphenylpyrazole-3-carboxamide derivatives as potent, reversible, and selective monoacylglycerol lipase (MAGL) inhibitors. Journal of medicinal chemistry. 2018;61(3):1340-54.

[53] Ishiyama M, Miyazono Y, Sasamoto K, Ohkura Y, Ueno K. A highly watersoluble disulfonated tetrazolium salt as a chromogenic indicator for NADH as well as cell viability. Talanta. 1997;44(7):1299-305.

[54] Hotsumi M, Tajiri M, Nikaido Y, Sato T, Makabe K, Konno H. Design, synthesis, and evaluation of a water soluble C5-monoketone type curcumin analogue as a potent amyloid $\beta$ aggregation inhibitor. Bioorganic \& medicinal chemistry letters. 2019;29(16):2157-61

[55] Kirchner DK, Güntert P. Objective identification of residue ranges for the superposition of protein structures. BMC bioinformatics. 2011;12(1):1-11.

[56] Park JH, Liu Y, Lemmon MA, Radhakrishnan R. Erlotinib binds both inactive and active conformations of the EGFR tyrosine kinase domain. Biochemical Journal. 2012;448(3):417-23.

[57] Radwan AA, Ghorab MM, Alsaid MS, Alanazi FK. Novel ethyl 1, 5disubstituted-1H-pyrazole-3-carboxylates as a new class of antimicrobial agents. Acta Pharmaceutica. 2014;64(3):335-44.

[58] Akbarzadeh T, Rafinejad A, Fallah-Tafti A, Tiwari R, Nasrolahi Shirazi A, Mandal D, et al. Synthesis and Evaluation of Ethyl 2, 4-dioxo-4-arylbutanoate Derivatives as Src Kinase Inhibitors. Journal of Sciences, Islamic Republic of Iran. 2015;26(4):321-5.

[59] Hasan P, Pillalamarri VK, Aneja B, Irfan M, Azam M, Perwez A, et al. Synthesis and mechanistic studies of diketo acids and their bioisosteres as potential antibacterial agents. European Journal of Medicinal Chemistry. 2019; 163:67-82

[60] Bracken C, Baumann M. Development of a Continuous Flow Photoisomerization Reaction Converting Isoxazoles into Diverse Oxazole Products. The Journal of Organic Chemistry. 2020;85(4):2607-17.

[61] Yamali C, Gul HI, Ece A, Bua S, Angeli A, Sakagami H, et al. Synthesis, biological evaluation and in silico modelling studies of 1, 3, 5-trisubstituted pyrazoles carrying benzenesulfonamide as potential anticancer agents and selective cancer-associated hCA IX isoenzyme inhibitors. Bioorganic chemistry. 2019;92:103222.

[62] Batchu H, Bhattacharyya S, Kant R, Batra S. Palladium-catalyzed chelationassisted regioselective oxidative dehydrogenative homocoupling/orthohydroxylation in N-phenylpyrazoles. The Journal of Organic Chemistry. 2015;80(15):7360-74.

[63] Alvarado M, Goya P, Macías-González M, Pavón FJ, Serrano A, Jagerovic $\mathrm{N}$, et al. Antiobesity designed multiple ligands: Synthesis of pyrazole fatty acid amides and evaluation as hypophagic agents. Bioorganic \& medicinal chemistry. 2008;16(23):10098-105

[64] Chen LW, Wang PF, Tang DJ, Tao XX, Man RJ, Qiu HY, et al. Metronidazole containing pyrazole derivatives potently inhibit tyrosyl-tRNA synthetase: design, synthesis, and biological evaluation. Chemical biology \& drug design. 2016;88(4):592-8. 